\title{
Investigation into Big Data Impact on Digital Marketing
}

\author{
Ketty Grishikashvili, Open University, UK \\ S. Dibb, Open University, UK \\ M. Meadows, Open University, UK
}

\begin{abstract}
The increased accessibility of digitally sourced data and advance technology to analyse it drives many industries to digital change. Many global businesses are talking about the potential of big data and they believe that analysing big data sets can help businesses derive competitive insight and shape organisations' marketing strategy decisions. Potential impact of digital technology varies widely by industry. Sectors such as financial services, insurances and mobile telecommunications which are offering virtual rather than physical products are more likely highly susceptible to digital transformation. However the interaction between digital technology and organisations is complex and there are many barriers for to effective digital change which are presented by big data. Changes brought by technology challenges both researchers and practitioners. Various global business and digital tends have highlights the emergent need for collaboration between academia and market practitioners. There are "theories-in - use” which are academically rigorous but still there is gap between implementation of theory in practice. In this paper we identify theoretical dilemmas of the digital revolution and importance of challenges within practice. Preliminary results show that those industries that tried to narrow the gap and put necessary mechanisms in place to make use of big data for marketing are upfront on the market.
\end{abstract}




\section{Introduction}

Advances in digital technology have made a significant impact on marketing theory and practice. Technology expands the opportunity to capture better quality customer data, increase focus on customer relationship, rise of customer insight and Customer Relationship Management (CRM). Availability of big data made traditional marketing tools to work more powerful and innovative way. In current digital age of marketing some predictions of effects of the digital changes have come to function but still there is no definite answer to what works and what doesn't in terms of implementing the changes in an organization context.

The choice of this specific topic is motivated by the need for a better understanding for impact of digital on marketing field. This paper will discusses the potential positive impact of the big data on digital marketing. It also presents the evidence of positive views in academia and highlights the gap between academia and practices. The main focus is on understanding the gap and providing recommendation for filling it in. The aim of this paper is to identify theoretical dilemmas of the digital revolution and importance of challenges within practice. Preliminary results presented here show that those industries that tried to narrow the gap and put necessary mechanisms in place to make use of big data for marketing are upfront on the market. In our discussion we shall identify these industries and present evaluations of which industry sectors would need to be looking at understanding of impact that big data may have on their practices and businesses.

\section{Digital Marketing and Big Data}

In early 90's when views about digital changes has started Parsons at el (1998) believed that to achieve success in digital marketing consumer marketers should create a new model with five essential elements in new media environment. Figure below shows five success factors and issues that marketers should address around it. 


\section{DIGITAL HAREETIMG OF TOHORROW}

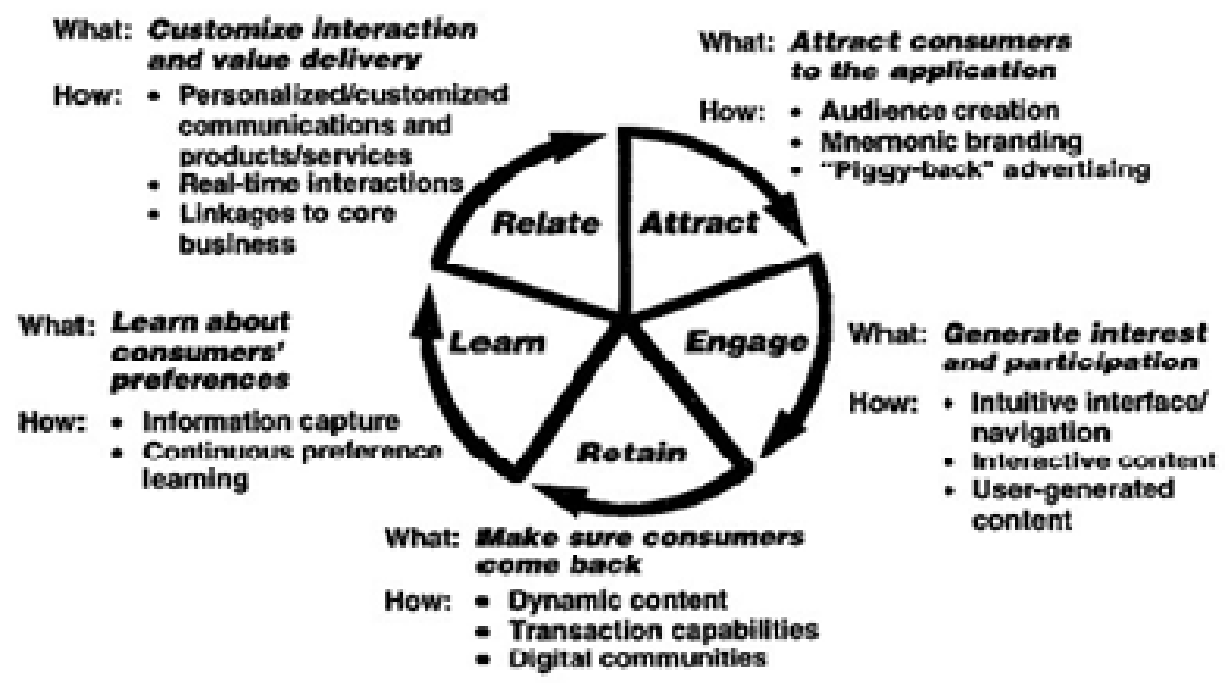

Figure 1. Digital marketing Framework and levers Parson et al (1998)

Today in digital age of marketing some predictions of effects of this changes have come to function but still there is no define answers on what works and what doesn't in terms of implement it in organization context. S. Dibb (2012). There are deferent explanations, arguments and views about impact of digital on marketing strategy in the literature.

At first, it is important to define what is meant by digital marketing, what are the challenges brought by it and then understand how it is adopted. Simply, Digital Marketing (2012) can be defined as "a sub branch of traditional Marketing using modern digital channels for the placement of products such as downloadable music, and primarily for communicating with stakeholders e.g. customers and investors about brand, products and business progress”. According to (Smith, 2007) the digital marketing refers "The use of digital technologies to create an integrated, targeted and measurable communication which helps to acquire and retain customers while building deeper relationships with them”. There are a number of accepted theoretical frameworks however as Parsons et al (1998) suggested potentialities offered by digital marketing need to consider carefully where and how to build in each organization by the senior managers. The most recent developments in this area has been triggered by growing amount of digital data now known as Big Data. 
Tech American Foundation (2004) defines Big Data as a "term that describes large volumes of high velocity, complex and variable data that require advanced techniques and technologies to enable the capture storage, distribution, management and analysis of information”. D. Krajicek (2013) argues that the big challenge of Big Data is the ability to focus on what is meaningful not on what is possible, with so much information at their fingerprint marketers and their research partners can and often do fall into "more is better" fallacy. Knowing something and knowing it quickly is not enough. Therefore to have valuable Big data it needs to be sorted by professional people who have skills to understand dynamics of market and can identify what is relevant and meaningful. G. Day (2011). Data should be used for achieve competitive advantage by creating effective relationship with the target segments. According to K. Kendall (2014) with de right capabilities, you can take a whole range of new data sources such as web browsing, social data and geo tracking data and develop much more complete profile about your customers and then with this information you can segment better. Successful Big Data initiatives should start with a specific and clearly defined business requirement then leaders of these initiatives need to assess the technical requirement and identify gap in their capabilities and then plan the investment to close those gaps (Big Data Analytics 2014)

\section{The Impact and Current Challenges}

Bileviciene (2012) suggest that well conducted market research is the basis for successful marketing and well conducted study is the basis of successful market segmentation. Generally marketing management is broken down into a series of steps, which include market research, segmentation of markets and positioning the company's offering in such a way as to appeal to the targeted segments. (OU Business school, 2007) Market segmentation refers to the process of defining and subdividing a large homogenous market into clearly identifiable segments having similar needs, wants, or demand characteristics. Its objective is to design a marketing mix that precisely matches the expectations of customers in the targeted segment (Business dictation, 2013). The goal for segmentation is to break down the target market into different consumers groups. According to Kotler and Armstrong (2011) traditionally customers were classified based on four types of segmentation variables, geographic, demographic, psychographic and behavioral. 
There are many focuses, beliefs and arguments in the field of market segmentation. Many researchers believe that the traditional variables of demographic and geographic segments are out-dated and the theory regarding segmentation has become too narrow (Quinn and Dibb, 2010). According to Lin (2002), these variables should be a part of a new, expanded view of the market segmentation theory that focuses more on customer's personalities and values. Dibb and Simkin (2009) argue that priorities of market segmentation research aim to exploring the applicability of new segmentation bases across different products and contexts, developing more flexible data analysis techniques, creating new research designs and data collection approaches, however practical questions about implementation and integration have received less attention. According to S. Dibb (2012) in academic perspective segmentation still has strategic and tactical role as shown on figure below. But in practice as Dibb argues "some things have not changed" and:

- $\quad$ Segmentation's strategic role still matters

- Implementation is as much of a pain as always

- $\quad$ Even the smartest segments need embedding

Segmentation still has both strategic \& tactical roles...

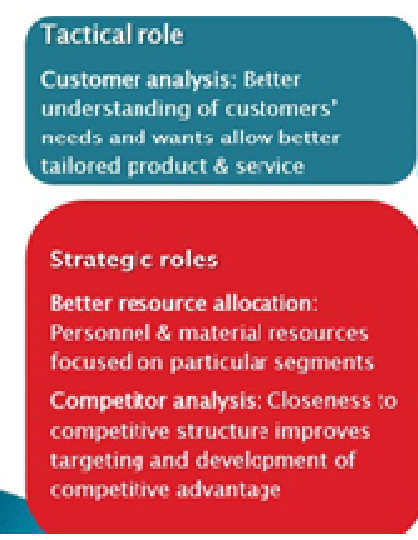

- Data bashing capabilities enable multipe segment dimensions to be used - May eahance the capacity fo- better tailored marketing programmes

Figure 2: role of segmentation S. Dibb (2012)

Dilemmas with the Implementation of digital change arise for various reasons. Some academics believed that greater access to data would reduce the need for more traditional segmentation but research done on the field shows that traditional segmentation works equal 
to CRM ( W. Boulding et al 2005). Even though the marketing literature offers insights for improving the effectiveness of digital changes in marketing filed there is limitation on how an organization adapts its customer information processes once the technology is adjusted into the organization. (J. Peltier et al 2012) suggest that there is an urgent need for data management studies that captures insights from other disciplines including organizational behavior, change management and technology implementation.

Reibstein et al (2009) also highlights the emergent need for collaboration between academia and market practitioners. They point out that there is a "digital skill gap" within the marketing filed. Authors argue that there are "theories-in -use" which are academically rigorous but still there is gap between implementation of theory in practice. Changes brought by technology and availability of digital data challenges both researchers and marketers.

In the era of the new digital economy and eSociety, demand for understanding how to manage and analyze the large scale commercial information (Big data) in an effective and efficient way for business success is very high. According to E. Smith (2001) Transformation data to information and knowledge helps shape effective strategies to manage knowledge for market research. Market research is one of the most powerful business tools, which enables companies to make important business decisions in the development of new commercial opportunities.

\section{Industry Perspective}

Royle and Laing (2013) suggest that further marketing research should move towards the identification of best practice approaches. Potential impact of digital technology varies widely by industry. According to Big Data Analytics (TDWI research 2011) by the 2011 big data analytics adoption rates differ by plus or minus 9 per cent between industries as demonstrated on the figure below.

Industry Big data analytics adoption \%

\begin{tabular}{l}
\hline InvestmentBanking \\
InsuranceTelecom \\
Manufacturing \\
Transport\& \\
Logistics
\end{tabular}

InvestmentBanking InsuranceTelecom Transport\& Logistics 39

36 


RetailBanking
CentralGovernment
Energy\&Utility
OtherActivitie
s Retail
Healthcare

RetailBanking

CentralGovernment

Energy\&Utility

$s$ Retail

Healthcare

35
35
34
31
31
30
34

Figure 3. 2011 Big Data Analytics Adoption Rates (Big Data Analytics 2014)

Big Data is already making a big impact on certain industries such as the healthcare, industrial, and retail sectors. With the exception of the government sector, sectors such as financial services, insurance and mobile telecommunications which are offering virtual rather than physical products are more likely highly susceptible to digital transformation. Big Data technology will help financial institutions maximize the value of data and gain competitive advantage and minimize costs.

For example according to (The Economist 2012) digital transformation in financial services has enabled the cost effective provision now they are using high-performance computing to identify complex patterns of fraud within unstructured data which was not previously possible. Same time Retailers are racing to become better at "slicing and dicing” reams of data they collect from multiple channels - online, stores, call centers, catalogues and smart phones. They are using business analytics to get insight into retail KPIs (outcome measures) or Metrics (operational activities that serve as leading or lagging indicators). The primary goal is to drive significant improvements in the sector, more timely responses to information requests, cost reduction initiatives and better service to customers. (D. Selinger 2013) However the interaction between digital technology and organizations is complex and there are many barriers for to effective digital change which are presented by big data. According to (Jarvinen et al 2012) from the marketing perspective availability of digital data created two major opportunities for all type of industries. Firstly they have access to enormous range of digital tools which can be utilized for marketing purposes, and secondly, the digital environment has made marketing more measurable by improving marketers ability to assess, collect, process and report data on marketing activities. (Pauwels et al, 2009) 


\section{Discussion and Recommendations}

Understanding digital technology driven change in marketing is very crucial to marketers, as it involves new customers, new brands, new markets and even new market leaders.

Table below shows additional benefits offering by digital marketing against traditional marketing.

\begin{tabular}{|c|c|c|}
\hline Dimensiog & Tradlitonal Markeling & Inikrost Muketing \\
\hline Time perppective & Short-lem Focus & Long iermifocus \\
\hline Prodominant markcting funtiog & Markcting mix. & $\begin{array}{l}\text { Marketing mix supported on: } \\
\text { - Customser Relationship Management } \\
\text { - Enteprise Resource Planning } \\
\text { - Relationship Marketing } \\
\text { - Knowlodge Managcment } \\
\text { - Supply Chain Management. }\end{array}$ \\
\hline Distribution model & Truditional durribution & Disiniermodiation and ogber intermoliation \\
\hline Value Croution & $\begin{array}{l}\text { Information was an } \\
\text { element of support }\end{array}$ & Information has value, is an ased \\
\hline
\end{tabular}

Table 1: Traditional Marketing versus Internet Marketing (Tiago, M.T and Tiago, F. 2012)

It is unarguable that evolving technologies continually offer new opportunities and challenges for industry practitioners, education and academics. In their empirical study (Roberts, J. H, Kayande, U, Stremersch, S. 2013) where they try to find the answer for following questions does marketing science research affect marketing practice? note that the impact of marketing science on marketing decisions has been largely felt in areas which are of the greatest importance to the firm. Managers are aware of the marketing science tools available to them, and there is a correlation between managers, academics, and intermediaries on the perception of the impact of those tools. However, not all sectors have implemented the digital changes brought by big data. This reasons for this remains to be investigated I the future work as part of this research project.

\section{Conclusions}

Looking into academic literature, the majority of studies within digital marketing discuss theoretical dilemmas of the digital revolution. Leeflang et al (2014) point out that, there is an increased number of quantitative studies investigating specific research questions relevant to digital marketing, however there are only a few studies that aim to identify importance of 
challenges within practice. According to existing literature to succeed in today's business world, companies must adopt not just the technologies and talent to manage big data, but also the organizational culture. Any industry should adopt a culture of innovation, allow opensource technologies to make change and put data at the heart of every decision they make. It is also important that industry universities and academia continue to work together to feel the existing skill gap in the field.

The choice of this specific topic was motivated by the need for a better understanding for impact of digital on marketing field.A primarily literature search was conducted during February 2014 using Web base database. The literature search was limited to peer-review journals and was based on words such as "Digital marketing", "Big Data" "Marketing Segmentation”, “E- Business”, "Digital change” and "Implementation theory in practice”. Search also was conducted in International journal of Marketing, International journal of Management, Journal of Marketing Management and journal of Marketing. Totally 25 research studies were selected from year 1998 till 2014 to analyze current situation in marketing field. Research also considers and analyses academics and professionals views in the aria available on the digital sources such as Harvard business review, marketing week, Big Data analytics, ZDNet.

This paper discussed the potential positive impact of the big data on digital marketing. It also presented the evidence of positive views in academia and highlights the gap between academia and practices. The main focus is on understanding the gap and providing recommendation for filling it in. The aim of this paper was to identify theoretical dilemmas of the digital revolution and importance of challenges within practice. Preliminary results presented here show that some industries that tried to narrow the gap and put necessary mechanisms in place to make use of big data for marketing are upfront on the market. 


\section{References}

Bileviciene, T. (2012).”Opportunities and development of implementation of multiple statistical methods in marketing” International scientific conference practice and Research in Private and Public sector - 2012. April 26 -27, 2012

Brynjolfsson, E and Schrage, M. (2009) The new faster face of innovation. Thanks to technology, change has never been so easy-or so cheap. Wall street journal and sloan management review.

Boulding, W, Staelin, R, Ehret, M and Johnston, W. J (2005).“A customer relationship management roadmap: what is known, potential pitfalls, and where to go”, Journal of Marketing, Vol. 69 (October), pp. 155-166.

Business Dictation (2014). Available at:

http://www.businessdictionary.com/definition/market- segmentation.html\#ixzz2M1bGwXyJ. [Accessed 15 February 2014]

Big Data Analytics (2013). Available at:

http://www.sas.com/offices/europe/uk/downloads/bigdata/eskills/eskills.pdf. [Accessed 15 February 2014]

Dibb, S and Quinn, L (2010) "Evaluating Market-Segmentation Research Priorities: Targeting Re- Emancipation”, Journal of Marketing Management, Vol.26, Iss13/14,pp.1239-1255

Dibb, S, (2012) “Market segmentation an old story with new twist”, Open University Business School. Available at: http://levittgroup.org.uk/pdf/2012/speakersnotes/Sally-Dibb.pdf. [Accessed 15 February 2014]

Day, S. G, (2011) “Closing the Marketing Capabilities Gap” Journal of Marketing. Vol. 75, 183-195

Hemsley, S, (2014) “Big data: Embracing the elephant in the room”. Marketing Week. Available at: http:/www.marketingweek.co.uk/big-data-embracing-the-elephant-inthe-room/3030939.article. [Accessed 25 February 2014]

Harvard Business Review (2014) Available at: http://hbr.org/. [Accessed 25 February 2014

Jarvinen, J, Tollinen, A, Karjaluoto, H, and Jayawardhena, C, (2012) "Digital and Social Media Marketing Usage in B2B Industrial Section” The marketing management journal. Volume 22, Issue 2, pages 102-117 
Kotler, P and Armstrong, G, (2011) “Principles of Marketing” 14th ed., Person Prentice Hall, New Jersey

Karlsoon, D andDarnfors, D (2012)”Towards a new paradigm in market Segmentation” Linnaeus

University SE-391 82 Kalmar/SE-351 95 Vaxjo

Krajicek, D, (2013) “ How Big Data Becomes Better Decisions: The Insight Hunters” Available at: http://blog.gfk.com/2013/05/how-big-data-becomes-better-decisions-theinsight-hunters-role/. [Accessed 15 February 2014]

Lin, C (2002) "Segmenting Customer Brand Preference: Demographic or Psychographic", Journal of Product \& Brand Management, Vol. 11, pp.249-268

Lattice engines (2014) Big data for sales. Available at: http://www.latticeengines.com/uploads/resource-center/whitepapers/documents/LatticeEngines-eBookBigData-Big-Sales.pdf [Accessed 15 February 2014]

Leeflang, S.H, Verhoef, P. C, Dalstrom, P, Freundt, T, (2013) “Challenges and solutions for marketing in digital era” European management journal 32 92014 1-12

Marketing Week (2014) Available at: http://www.marketingweek.co.uk/. [Accessed 15 February 2014] Mathur, M and Samma, S, (2010) “A Study on Customer Relationship Management Practices in Selected Organised Retail Stores in Udaipur City“ Pacific Business Review - A Quarterly Refereed Journal.

Parsons, M. Z and Waitman, R (1998) “Organizing Today For The Digital Marketing Of Tomorrow”. Journal of interactive Marketing. John Wiley \& Sons, Inc. and Direct Marketing Educational Foundation, Inc. CCC 1094-9968/98/010031-16

Peltier, J. W, Zahay, D and Lehmann, D. R (2012) “Organisational learning and CRM success: A model for linking organisational practices, Customer data quality and performance.” Journal of interactive marketing 27 1-13

Pauwels, K, Ambler, T., Clark,B. H., Lapointe, P., Reibstein, D., Skiera, B., et all (2009) “ Dashboards as a service: Why,What, How, and What research is needed? Journal of service research, 12 (2), 175-189

Royle, j and Laing, A, (2013) “The digital marketing skill gap: Developing a digital marketer model for the communication industry”. International Journal of Information Management 34 65-37. 
Roberts, J. H, Kayande, U, Stremersch, S. (2013) "From academic research to marketing practice: Exploring the marketing science value chain” Intern. J. of Research in Marketing

Tiago, M. T and Tiago F (2012) "Revisiting the Impact of Integrated Internet Marketing on Firms’Online

Performance: European Evidences” Procedia Technology 5 ( 2012 ) 418 - 426

Tech American Foundation, (2004).Demystifying Big Data-IBM. Available at:

http://www-304.ibm.com/industries/publicsector/fileserve?contentid=239170. [Accessed 15

February 2014]

Simply Digital Marketing. (2014). What is digital marketing? Available at:

http://www.simplydigitalmarketing.com/what-is-digital-marketing Accessed 17.02.12

[Accessed 15 February 2014]

Smith, R. D, (2001). Managing Organizational Knowledge as a Strategic Asset. Journal of Knowledge Management, Volume 5, Number 1, 8-18.

Wymbs, C. (2011). Digital marketing: The time for a new “Academic Major” has arrived. Journal of Marketing Education, 33(1), 93-106.

ZDNet (2014) “ Big Data : Big Hype or Big Hope? Available at: http://www.zdnet.com/. [Accessed 15 February 2014] 